\title{
KETIKA MEMBUNUH MENJADI SEBUAH PENYELESAIAN: SEBUAH TINJAUAN FENOMENOLOGIS MENGENAI TINDAKAN SESEORANG MELAKUKAN PEMBUNUHAN
}

\author{
Agus Wahyudi \\ Universitas Negeri Surabaya \\ e-mail: masaguslumos@gmail.com
}

\begin{abstract}
Abstrak: Pembunuhan adalah tindakan keji yang merenggut nyawa orang lain. Semua orang bisa menjadi pembunuh. Latar belakang sosio kultural (umur, jenis kelamin, sosial ekonomi, etnis dan agama) bukanlah alasan bagi seseorang untuk melakukan pembunuhan. Salah satu faktor disebut sebagai motif pembunuhan. Penelitian kualitatif ini menggunakan data primer. Dengan menggunakan 5 subjek dalam penelitian ini. Dari 5 subjek penelitian tersebut, ada 4 motif untuk membunuh, yaitu poligami, uang, pinjaman atau utang, dan frustasi.
\end{abstract}

Kata kunci: motif, pembunuhan atau pembunuh, orang lain

\begin{abstract}
Murder is an evil action to take the soul of others. Everyone can be a murderer. Sociocultural background such as: age, sex, socio-economic, ethnic, and religion is not the reason for someone to kill others. Many factors make someone decide to kill others. One of the factors is known as killing motive. This qualitative research used the primary data. The subject were 5 people. There were 4 motives to kill, they are polygamy, money, debt, and frustration.
\end{abstract}

Keywords: Motive, murder, the other people

\section{PENDAHULUAN}

Kejahatan pembunuhan terhadap jiwa orang lain terus terjadi dan menjadi pemberitaan luas oleh media massa (Tony McEnery, Lancaster, Mark McGlashan, 2015). Pembunuhan merupakan perilaku seseorang atau sekelompok orang yang berakibat hilangnya nyawa orang lain (David F. Luckenbill, Lonnie H. Athens dan Marvin E. Wolfgang, 2015). Kejadian pembunuhan dilatarbelakangi oleh berbagai sebab sehingga seseorang merencanakan, memutuskan, dan mengeksekusi pembunuhan terhadap orang lain (John L. Oliffe, R.N., Ph.D., Christina, S.E. Han, M.A., Murray Drummond, Ph.D., Estephanie Sta. Maria, B.A., Joan L. Bottorff, Ph.D., and Genevieve Creighton, Ph.D., 2015). Ketika seseorang telah menjadi korban pembunuhan maka dipastikan ia mengalami kematian (Joseph Murray, Daniel Ricardo de Castro Cerqueira, Tulio Kahn, 2013).

Berbagai faktor penyebab seringkali menjadi daya penggerak/pemicu bagi seseorang untuk melakukan pembunuhan (Mohammad Abdul Mohit and Mohamed Hassan Elsawahli Hannan, 2012).

Dalam kasus pembunuhan berencana (planned murder), biasanya seorang calon pembunuh sudah mengetahui siapa calon korban yang akan dibunuhnya, sedangkan dalam kasus pembunuhan tak berencana (unplanned murder), seseorang membunuh orang lain karena adanya konflik emosional antara dirinya dengan calon korban (Robin A Robinson, Simon Visiting Professor, David Gadd, 2014). Konflik sosio-emosional ditengarai oleh suatu masalah yang tak bisa terselesaikan dengan baik (Masrun, 1974). Jenis 
pembunuhan lain adalah pembunuh bayaran, di mana seseorang menjadi pembunuh bayaran (payment murder) karena ia memperoleh imbalan dari orang lain yang memberikan perintah untuk membunuh (David F. Luckenbill, Lonnie H. Athens, dan Marvin E. Wolfgang, 2015). Seorang pembunuh bayaran secara sadar atau tidak sadar akan berhadapan dengan risiko sangsi hukum yang diberikan oleh aparat penegak hukum (Sefti Octaviani, 2014). Namun seseorang yang memberi perintah untuk membunuh pun tidak akan luput dari perhatian penegak hukum (Ilie Magdalena Ioana, Sefti Octaviani, 2014).

Seorang pembunuh sebenarnya orang yang paling bertanggung jawab dalam penghilangan nyawa orang lain (Ilie Magdalena, 2014) sehingga ia harus siap untuk berhadapan dengan pihak aparat hukum yang menyelesaikan kelanjutan dari peristiwa pembunuhan tersebut (Selvi Octaviani, 2014). Namun, ketika seseorang sudah mengeksekusi pembunuhan, pada umumnya ia akan melarikan diri dan berusaha agar tidak ditangkap oleh aparat kepolisian. Ada pula seseorang secara sadar menyerahkan diri untuk diproses secara hukum oleh kepolisian, setelah ia membunuh orang lain (Ilie Magdalena, 2014).

Sampai kapan pun kasus pembunuhan sulit untuk dihilangkan, yang bisa dilakukan adalah bagaimana mengurangi, mencegah, atau menghindari peristiwa pembunuhan (Soltankhah, Shapoura, Rahmani, M., Akbari, B., Darvishi, 2013). Pembunuhan akan tetap terus terjadi dan bisa dialami oleh siapa pun, selama masih ada konflikkonflik sosio-emosional yang belum terselesaikan antara individu satu dengan individu yang lainnya (Michael C. Dillbeck and Kenneth L. Cavanaugh, 2015).

Konflik sosio-emosional memang menjadi pemicu perilaku pembunuhan, karena seseorang merasa kecewa, sakit hati, atau dendam pada orang lain. Secara ekstrem pelampiasan rasa kecewa, sakit hati, dendam atau amarah dilampiaskan dengan cara membunuh orang lain. Hal ini banyak terjadi pada kasus-kasus pembunuhan di masyarakat (Widyatmoko Cikal, Ika Febrian Kristiana, 2012).

Pembunuhan pada hakikatnya bertentangan dengan norma hukum dan norma agama, serta membahayakan bagi penghidupan dan kehidupan masyarakat. Meskipun demikian tetap saja ada sebagian anggota masyarakat yang melakukan tindak kejahatan tersebut (David F. Luckenbill, Lonnie H. Athens dan Marvin E. Wolfgang, 2015). Dan ironisnya minat para pemerhati masalah-masalah sosial di Indonesia untuk mengkaji fenomena pembunuhan yang terjadi di tengah-tengah masyarakat tampak masih kurang. Padahal sebagai fenomena sosial, pembunuhan merupakan topik yang sangatlah menarik dan perlu dikaji secara luas dan mendalam. Kenyataan inilah yang mendorong penulis untuk mengangkat permasalahan tersebut sebagai topik dalam penelitian ini. Dalam tulisan hasil penelitian ini akan diuraikan gambaran motif-motif yang mendorong seseorang untuk menjadi pembunuh.

\section{METODE PENELITIAN}

\section{Subjek Penelitian}

Subjek dalam penelitian ini adalah mereka yang terbukti melakukan pembunuhan dan pernah masuk penjara. Usia, jenis kelamin, suku bangsa, atau status sosial ekonomi tak dibatasi dalam penelitian. Jumlah subjek dalam penelitian ini sebanyak lima orang. Kelima subjek tersebut adalah laki-laki dengan rentang usia 14-55 tahun.

\section{Teknik Pengambilan Data}

Pengambilan data dalam penelitian ini dengan menggunakan data primer (primary data) dengan teknik purposive sampling. (Denzin, 
2011) Di mana beberapa subjek penelitian telah diambil berdasarkan ketentuan yang berhubungan dengan permasalahan yang dikaji, terutama yang pernah melakukan tindakan kejahatan pembunuhan (Moleong, 2007:4).

\section{Desain Penelitian}

Penelitian ini bersifat kualitatif, artinya penelitian yang hendak mengungkapkan kasuskasus perilaku dengan analisis terhadap motifmotif pembunuhan dari para pelaku kejahatan (Moleong, 2007: 4), Analisis dilakukan dengan melihat gambaran berbagai kasus pembunuhan. Dengan menggunakan perspektif fenomenologis (Denzin, 2011; 117), khusus dalam paradigma struktural fungsional Roibert K. Merton dalam melihat perilaku menyimpang dalam hal ini tindakan pembunuhan yang dilakukan oleh subjek.

\section{KERANGKA PEMIKIRAN PEMBUNUHAN SEBAGAI PERILAKU MENYIMPANG DALAM STRUKTURAL FUNGSIONAL}

Struktural fungsional melihat penyimpangan terjadi pembentukan normal dan nilai yang dipaksakan oleh institusi dalam masyarakat. Penyimpangan dalam hal ini tidaklah terjadi secara alamiah namun terjadi ketika pemaksaan atas seperangkat aturan main tidak sepenuhnya diterima oleh orang atau sekelompok orang, dengan demikian penyimpangan secara sederhana dapat dikatakan sebagai ketidaknormalan secara aturan, nilai, atau hukum. Salah satu teori utama yang dapat menjelaskan mengenai penyimpangan ini adalah teori anomie dari Durkheim dan dari Merton.

Durkheim secara tegas mencoba meyakinkan bahwa terdapat hubungan terbalik antara integrasi sosial dan pengaturan sosial dengan angka bunuh diri. Sekurangnya terdapat dua dimensi dari ikatan sosial (social bond), yakni integrasi sosial dan aturan sosial (social regulation) yang masing-masing independen atau dalam istilah lain, besaran integrasi tidak menentukan besaran pengaturan, demikian pula sebaliknya, namun keduanya memengaruhi ikatan sosial. Integrasi sosial dapat diterjemahkan sebagai keikutsertaan seseorang dalam kelompok dan institusi di mana aturan sosial merupakan pengikat kesetiaan terhadap norma dan nilai-nilai dalam masyarakat. Mereka yang sangat terintegrasi masuk dalam kategori 'altruism', dan yang sangat tidak terinteraksi dalam kategori 'egoism'. Demikian pula mereka yang sangat taat aturan masuk dalam kategori ' $\mathrm{fa}$ talism' dan mereka yang sangat tidak taat masuk dalam kategori 'anomie'.

Perspektif anomie dari Durkheim dikembangkan oleh Merton sebagai bentuk alienasi diri dari masyarakat di mana diri tersebut membenturkan diri dengan norma-norma dan kepentingan yang ada di masyarakat. Dalam menjelaskan hal ini, Merton memfokuskan pada dua variabel, yakni tujuan (goals) dan 'legitimate means' ketimbang integrasi sosial dan pengaturan sosial. Dua dimensi ini menentukan derajat adaptasi masyarakat sesuai dengan tujuan-tujuan kultural (apa yang diinginkan oleh masyarakat mengenai kehidupan ideal) dan cara-cara yang dapat diterima di mana seorang individual dapat menuju tujuan-tujuan kultural. Merton sendiri membagi derajat adaptasi dengan lima kombinasi, yakni 'conformity', 'innovation', 'ritualism', 'retreatism', dan 'rebellion'.

\section{Gambaran Subjek Penelitian}

\begin{tabular}{|c|c|c|c|c|c|c|c|}
\hline No & Subjek & Umur & $\begin{array}{c}\text { Jenis } \\
\text { Kelamin }\end{array}$ & $\begin{array}{c}\text { Pendidi } \\
\text { kan }\end{array}$ & Pekerjaan & Korban & $\begin{array}{c}\text { Alasan } \\
\text { Membunuh }\end{array}$ \\
\hline 1 & Warja & 30 & L & - & Pengangguran & 2 orang & Poligami \\
\hline 2 & Su & 14 & L & SD & Tukang parkir & 2 & Dibayar \\
\hline 3 & Sahr & 35 & L & - & $\begin{array}{c}\text { Karyawan } \\
\text { Swasta }\end{array}$ & 1 & Dendam \\
\hline 4 & IRP & 32 & L & - & Karyawan & 1 & $\begin{array}{c}\text { Perceraian } \\
\text { dan Dendam }\end{array}$ \\
\hline 5 & MR & 23 & L & SMA & Pengusaha & 1 & $\begin{array}{c}\text { Utang- } \\
\text { piutang }\end{array}$ \\
\hline
\end{tabular}




\section{Subjek 1 (Warja)}

Warja adalah subjek pertama, seorang lakilaki berusia 30 tahun dan menjalankan poligami. Ia berasal dari Jawa Barat. Menikah dengan Sunarsih (43 tahun) dan beranak 1 orang. Warja juga menikah lagi dengan Reni dan melahirkan seorang anak, namun tanpa diketahui oleh Sunarsih, istri pertamanya. Namun kemudian Sunarsih mengetahui kalau Warja berpoligami. Warja berniat untuk menceraikan Sunarsih, namun Sunarsih tak setuju atas niat tersebut. Demi memperlancar niatnya maka Warja pun membunuh Sunarsih. Warja tak peduli dengan sikap penolakan Sunarsih sehingga Warja pun membunuh Sunarsih. Setelah dibunuh, Sunarsih dikubur di dalam rumah. Sebagaimana yang dituturkan beliau;

"Lha yo opo mas, diajak ngomong nggena-nggena cek podho enak e, lha koq koq gak gelem, malah ngomong e nggawe munthap e wong lanang.... Pas wayahe petheng yo wis sak isok e... emboh piye sak onok e carane....

Agar tak diketahui oleh orang lain maka Warja juga membunuh Ningsih (34 tahun), adik iparnya. Ningsih juga dikubur bersama Sunarsih dalam satu lubang. Warja sempat meminta bantuan orang lain untuk menutup bekas kuburan dengan keramik agar tak ada bekas galian tanah. Para tetangga yang biasanya bercengkrama dengan Sunarsih dan Ningsih, tak menaruh curiga ketika Warja menjawab;

"yo terus tak tinggal minggat nang bogor,... emboh sing penting aku aman sik...

Warja pun segera mengontrakkan rumah Ningsih kepada orang lain. Orang lain tersebut sudah membayar uang kontrakan dan akan segera menempati rumah tersebut beberapa hari kemudian. Setelah ditempati, pengontrak rumah mencium bau busuk dari dalam lantai. Apalagi lantai itu goyang keramiknya bila terinjak kaki. Rupanya beberapa orang tetangga juga mencium aro- ma busuk dari rumah Ningsih. Setelah diusut ternyata bau busuk tersebut berasal dari dalam lantai keramik tersebut. Ketika digali, ditemukan 2 orang mayat yaitu Sunarsih dan Ningsih. Warja pun ditangkap dan dijebloskan ke penjara.

\section{Subjek 2 (Su)}

$\mathrm{Su}$ adalah seorang remaja laki-laki berusia 14 tahun. Ia lulusan SD dan bekerja serabutan dengan penghasilan tak menentu. Ketika Su mendapat tawaran dari 3 orang (P, Z, X) untuk membunuh Har (46 tahun) dengan upah bayaran 6 juta rupiah, Su langsung mengiyakan. P, Z, dan $\mathrm{X}$ adalah tiga orang lelaki yang merasa sakit hati, kecewa, dan dendam pada Har.

Mereka berutang uang dari Har, namun mereka belum bisa membayar ketika ditagih Har. Agar terhindar dari tagihan Har, maka P, Z, dan X berencana untuk membunuh Har. Hanya saja mereka tak mau melakukan sendiri. Mereka pun menyuruh Su dengan iming-iming 6 juta rupiah. Uang akan diberikan kepada Su, bila $\mathrm{Su}$ sudah berhasil melaksanakan tugas tersebut.

“... terus terang aja mas... aku sebenarnya gak tega melakukannya... makanya aku pinjam tangan orang lain buat niatanku itu....

Su mengajak Jos (21 tahun), seorang teman untuk melaksanakan tugas tersebut. Bersama dengan Jos, Su mendatangi rumah $\mathrm{Har}$ dan berpura-pura sebagai tamu. Kemudian $\mathrm{Su}$ dan Jos membunuh Har dengan cara memukul kepala Har. Mereka juga menusuk dengan senjata tajam dan korban meninggal dunia di tempat.

John, anak laki-laki Har, terbangun dari tidurnya, mendengar keributan di ruang tamu. Ketika keluar dari kamar tidur, John juga dibunuh oleh Su dan Jos. Kedua jenazah korban dimasukkan ke kamar mandi. Su dan Jos pun leluasa mengambil barang-barang Har berupa 
uang tunai, handphone, dan sepeda motor. Belum menikmati hasil kejahatan tersebut, Su dan Jos tertangkap polisi.

\section{Subjek 3 (Sahr)}

Sahr (35 tahun) sudah menikah dengan Ren dan diberi keturunan 1 orang anak berusia 4 tahun. Ren sering mengadukan ulah Ton (32) kepada suaminya. Ton adalah teman kerja suaminya sendiri. Sahr dan Ton sering bekerjasama untuk memperbaiki barang-barang elektronik yang rusak. Namun hal ini tak membuat Ton untuk menghentikan kebiasaan buruknya.

Ton tepat menggodai Ren, meskipun Ton tahu kalau Ren adalah istri temannya, Sahr. Sahr benar-benar merasa kecewa dengan ulah Ton karena Ton tak bisa menghargai dirinya, sebagai teman baik.

... lha wis ngerti bojone koncone lha koq sik diterak wae... bojoku dewe dikandani gak gelem nurut yo wis... awakmu karep ngunu... aku yo duwe karep dewe....

Agar dapat membalas kekecewaannya terhadap Ton, Sahr pun berniat melampiaskan dendamnya. Setelah seminggu membuat perencanaan dengan matang, Sahr pun mengajak Jali untuk menemui Ton. Mereka bertiga pesta miras dengan mengonsumsi alkohol, sampai Ton dalam keadaan mabuk. Ton pun diajak pergi ke lapangan. Dalam keadaan tak berdaya, Ton pun dibunuh oleh Sahr dan Jali. Sekujur tubuh Ton berdarah-darah karena dipukul dengan balok kayu yang berpaku. Bahkan paku-paku tersebut masih tersisa darah merah. Setelah tak bernyawa lagi, jenazah Ton ditinggalkan di tengah lapangan. Motor Supra Fit milik Ton diambil dan dijual seharga 1,1 juta kepada teman lainnya, Ya (44 tahun).

\section{Subjek 4 (IRP)}

IRP (32 tahun) adalah seorang duda dengan 2 orang anak. Kedua anak tersebut perempuan yaitu Kayla (7 tahun) dan Kaysa (4 tahun). Tahun 2009, IRP sudah bercerai dengan bekas istrinya, Nurbaeti (30 tahun). Meskipun tak lagi sebagai suami-istri, masing-masing membawa serta seorang anak. IRP hidup sebagai duda bersama dengan anak kedua, Kaysa, sedangkan Nurbaeti bersama dengan anak pertama, Kayla. IRP hidup bersama kedua orangtua kandungnya, sehingga Kaysa ikut dipelihara oleh kakek-neneknya. Setelah tiga tahun berlalu, IRP membunuh Kaysa, sebagai ungkapan rasa kecewa terhadap bekas istrinya. IRP tak mampu melampiaskan dendamnya terhadap bekas istrinya, karena tak pernah bertemu lagi. Karena itu, IRP hanya bisa melampiaskan kepada anak kandungnya sendiri, Kaysa.

\section{Subjek 5 (MR)}

MR (tidak disebutkan umurnya) ialah seorang lulusan SMA dari Australia dan kemudian berprofesi sebagai pengusaha. MR menjadi dalang pembunuhan terhadap teman sekolahnya sendiri, William Ling. Pembunuhan disebabkan oleh masalah utang piutang. William Ling pernah meminjam uang sebesar 800 juta rupiah dari MR, untuk membangun usaha warnet. Setelah sekian lama, William belum membayar utangnya, sehingga MR menyuruh 3 orang (AW, RB, dan MB) untuk menagih William.

Setelah berusaha keras untuk menagih, keorang tersebut tak berhasil mendapatkan uang tagihan. Mereka pun meluapkan kekesalannya, sehingga kepala William dipukul dengan martil dan lehernya dipiting. Kemudian William benarbenar dibunuh dan mati. Mayatnya dibungkus plastik dan dibuang di jalan kali sekretaris, Durui Kepa, Kebon Jeruk, Jakarta Barat. Selain 
membunuh William, para pelaku juga memeras keluarga korban.

\section{HASIL DAN PEMBAHASAN}

\section{Motif-Motif Pembunuhan}

Motif ialah dorongan yang menyebabkan seseorang melakukan suatu aktivitas tertentu untuk mewujudkan tujuan tertentu pula. Motif menjadi daya gerak yang mengarahkan seseorang untuk berbuat sesuatu (Sears, Freedman \& Peplau, 2004). Motif membunuh ialah suatu dorongan untuk membunuh orang lain. Akibat pembunuhan yaitu kematian dari korban. Ke-5 kasus pembunuhan yang dilakukan oleh 5 subjek (Warja, Su, Sahr, IRP, dan MR) berbeda-beda latar-belakangnya.

\section{Motif untuk Poligami}

Poligami ialah perkawinan seseorang lakilaki dengan lebih dari seorang istri (Dariyo, 2012a). Seorang laki-laki yang telah dewasa, sebenarnya hanya diperbolehkan untuk menikah dengan seorang wanita. Namun apabila ia mendapatkan izin dari istrinya, seorang laki-laki boleh melakukan poligami.

Tentu saja ada berbagai alasan bagi seorang laki-laki untuk berpoligami, antara lain: istri tak mampu memenuhi kebutuhan lahir-batin karena menderita sakit, istri mengalami kemandulan dan tak memberi keturunan, dan sebagainya (UU Perkawinan, 1974).

Subjek 1 Warja membunuh istri dan adik iparnya, karena Warja menjalankan poligami dan ingin menceraikan istrinya. Keinginan tersebut ditentang oleh istrinya sehingga Warja tak mau keinginannya terhalangi atau digagalkan oleh istrinya. Karena demi mencapai kemauannya, maka Warja pun tega membunuh istrinya sendiri.
Rupanya, Warja merasa takut kalau aksi pembunuhannya diketahui oleh orang lain. Sebelum diketahui oleh Ningsih, adik iparnya, maka Warja pun juga membunuh Ningsih. Warja semakin merajalela dalam melakukan aksi kejahatannya. Ketika hendak beribadah sholat, kepala Ningsih dibentur-benturkan ke dinding dan akhirnya mati. Dengan demikian, Warja melakukan pembunuhan terhadap 2 orang sekaligus dalam satu hari.

\section{Motif Mendapatkan Uang}

Uang ialah sarana untuk bertransaksi dalam urusan bisnis atau pekerjaan. Setiap orang berhak mendapatkan uang demi mempertahankan kehidupannya (Dariyo, 2012). Uang menjadi daya tarik yang sangat kuat bagi seseorang yang melakukan pembunuhan. Dengan uang, seseorang dapat memenuhi segala kebutuhan hidupnya. Bahkan dengan uang, seseorang bisa membeli apa pun yang dibutuhkannya. Dengan uang pula, seseorang bisa membayar orang lain untuk melakukan aksi pembunuhan terhadap orang lain. Motif mendapatkan uang itulah yang mendorong $\mathrm{Su}$ berani berbuat jahat menghilangkan nyawa orang lain.

Subjek 2, Su melakukan pembunuhan terhadap Har dan John karena ingin memperoleh upah uang sebesar 6 juta rupiah. Uang tersebut akan diberikan dari orang-orang (P, X, Z) yang menyuruhnya, kalau $S u$ telah berhasil melakukan tugasnya. P, X, dan Z berencana untuk membunuh Har, karena Har selalu menagih utang ketiganya agar segera dilunasi. Mereka sakit hati dan dendam atas tindakan Har yang terusmenerus menagihnya.

Demi mengatasi masalah tersebut, $\mathrm{P}, \mathrm{X}$ dan $\mathrm{Z}$ menyuruh Su untuk melakukan pembunuhan tersebut. Sebagai seorang remaja yang tak ber- 
penghasilan secara tetap, $\mathrm{Su}$ tak bisa berpikir panjang atas keputusan menerima perintah ke3-nya. Guna memperlancar aksinya, Su mengajak teman lain, Jos (21) yang umurnya lebih tua darinya. Akhirnya, Su dan Jos pun berhasil membunuh Har. Rupanya, Su dan Jos juga membunuh John, anak Har yang memergoki aksi jahat Su dan Jos. Sebelum memperoleh upah kejahatannya, Su dan Jos tertangkap polisi dan dipenjara.

\section{Motif Pelampiasan Dendam}

Dendam adalah bagian dari emosi. Emosi seringkali bersifat fluktuatif dan dinamis, tergantung penghayatan seseorang terhadap situasi dalam hidupnya (Santrok, 2005). Orang yang merasa dendam maka kondisi jiwanya tak stabil sehingga hidupnya tak merasa tenang (Masrun, 1975). Dendam ialah suatu perasaan sakit hati, kekecewaan, kekesalan, amarah, atau kepahitan karena ketidakmampuan seseorang untuk bisa menerima dan memaafkan perlakuan buruk dari orang lain. Perasaan dendam yang sulit diatasi dengan baik, akan tersimpan dalam hati. Dendam merupakan energi psikoemosional yang bersifat negatif bila pelampiasannya mengorbankan orang lain. namun kalau dendam tidak dilampiaskan (dikeluarkan) dengan baik, maka dendam akan menumpuk dan menjadi boomerang bagi diri sendiri.

Namun cara melampiaskan dendam yang buruk yang dilakukan dengan mengorbankan orang lain, maka memunculkan tindak kejahatan. Pembunuhan ialah suatu tindak kejahatan untuk menghilangkan nyawa orang lain. Salah satu sebab terjadinya pembunuhan karena faktor pelampiasan dendam. Kasus pembunuhan yang dilakukan oleh Sahr dan IRP adalah karena pelampiasan dendam.
Sahr membunuh Ton, karena Sahr merasa dendam terhadap Ton. Ton sering menggoda istrinya, padahal Sahr dan Ton bersahabat karib. Mereka pernah bekerja sama untuk memperbaiki barang-barang elektronik yang rusak. Namun persahabatan tersebut dikhianati oleh Ton. Ton tak pernah menghargai Sahr. Bahkan Ton sering menggodai istri Sahr. Karena itu, Sahr merencanakan dan membunuh Ton. Pembunuhan itu dibantu oleh teman lainnya, Jali.

Subjek ke-4 yaitu IRP juga melakukan pembunuhan terhadap Kaysa (4 tahun) anak kandungnya sendiri. IRP membunuh karena hendak melampiaskan perasaan dendam terhadap bekas istrinya. IRP masih kecewa terhadap perceraian di masa lalunya. Namun pelampiasan dendam tersebut tidak tepat karena IRP membunuh Kaysa, anak kandungnya sendiri. Padahal anak kandungnya tersebut tak tahu menahu terhadap masalah orangtuanya. Ketika kedua orangtuanya bercerai, Kaysa masih berusia 1 tahun.

\section{Motif Menagih Utang-Piutang}

Utang ialah suatu kewajiban yang harus dibayar, karena seseorang telah mendapatkan haknya terlebih dahulu. Selama belum lunas, utang masih harus diselesaikan dengan sebaikbaiknya. Bagi seseorang yang mempunyai utang, sampai kapan pun ia tak akan merasa tenang perasaan dan pikirannya, karena kewajibannya belum terselesaikan dengan baik.

Namun adakalanya seseorang berniat tidak membayar utangnya, meskipun ia sudah memiliki sejumlah uang. Hal inilah yang menimbulkan kekecewaan, sakit hati, atau dendam orang yang sudah pernah meminjamkan uangnya. Ketika dendam telah membakar emosi, maka dendam itu akan semakin membara dan membakar hidup seseorang. Penjelasan tersebut dialami oleh MR yang membunuh William karena utang-piutang. 
MR membunuh William, teman semasa sekolah SMA di Australia, karena William berutang sebesar 800 juta dari MR. William meminjam uang teman sekolahnya, untuk membangun usaha warnet (warung internet). Sebagian uang tersebut juga digunakan untuk berjudi. Ketika MR menagih utang, William tak pernah membayar, padahal usaha warnetnya sudah berjalan baik. MR pun merasa kesal, kecewa dan sakit hati atas ulah curang William.

MR menyuruh tiga orang temannya untuk menagih lagi kepada William. Usaha mereka juga gagal dan tak membuahkan apa-apa. Karena itu, mereka memukul kepala William dengan martil. Leher William juga dipiting. Setelah mati, mayatnya dibungkus plastik dan dibuang di pinggir jalan kali sekretaris, Jakarta Barat.

\section{Cara-Cara Pembunuhan}

Pembunuhan bisa dilakukan dengan berbagai cara baik dengan alat maupun tanpa menggunakan peralatan tertentu. Peralatan apa saja bisa digunakan oleh seseorang untuk menghilangkan nyawa orang lain, karena peralatan tersebut dianggap efektif dan efisien guna mencapai tujuan pembunuhan tersebut. Berbagai alat yang bisa digunakan untuk melakukan pembunuhan antara lain: senjata api, senjata tajam (pisau, belati, golok, pedang, samurai, paku), benda tumpul (kayu), tali-temali, dan sebagainya (David F. Luckenbill, Lonnie H. Athens dan Marvin E. Wolfgang, 2015).

Dalam kasus pembunuh subjek 2 (Su), subjek 3 (Sahr) dan subjek 5 (MR), proses pembunuhan dilakukan dengan menggunakan alat. Su bersama Yos menggunakan golok, pisau, dan kayu untuk menghabisi nyawa Hard an John. Sahr bersama Jali juga menggunakan kayu yang berpaku untuk membinasakan nyawa Ton.
MR bersama 3 orang teman (AW, RB dan MB) menggunakan martil dan tali-temali untuk menghilangkan nyawa William.

Warja (subjek 1) membunuh istri sendiri (Sunarsih) dan iparnya (ningsih) dengan tangan kosong. Warja membenturkan kepala istri dan iparnya ke tembok rumah. Secara tidak langsung, Warja menggunakan benda yaitu berupa tembok rumah guna membunuh para korbannya. Sementara itu, IRP (subjek ke-5) membunuh Kaysa, anak kandung sendiri dengan mencekik lehernya. Tentu saja, Kaysa tak berdaya menghadapi kejahatan ayahnya, sehingga ia pun mati.

\section{PEMBAHASAN}

Pembunuhan merupakan tindakan jahat yang dilakukan oleh seseorang untuk mematikan orang lain. Ketika seseorang sudah mati karena menjadi korban pembunuhan, maka tak ada lagi kesempatan baginya untuk menjalani kehidupannya. Pembunuhan bisa dilakukan oleh siapa pun, tanpa memandang latar-belakang hidupnya (umur, jenis kelamin, suku bangsa, status sosial ekonomi, dan sebagainya). Siapa pun juga bisa menjadi korban pembunuhan.

Karena itu baik pelaku pembunuhan maupun korban pembunuhan bisa dialami oleh siapa saja tanpa kecuali. Dalam penelitian ini, semua pelaku pembunuhan adalah laki-laki berusia antara 14-35 tahun. Mereka berasal dari latarbelakang pekerjaan yang berbeda-beda. Su adalah tukang parkir, Warja adalah pengangguran, MR adalah pengusaha, Sahr dan IRP adalah karyawan swasta. Latar-belakang motif pembunuhan juga berbeda-beda. Dalam hal ini ada 4 motif pembunuhan yaitu motif mendapatkan uang $(\mathrm{Su})$, motif berpoligami (Warja), motif balas dendam (Sahr), motif menagih utang-piutang (MR). 
Pembunuhan bisa dilakukan seorang diri, tetapi bisa juga dilakukan bersama dengan orang lain. Warja melakukan pembunuhan seorang diri dengan korban 2 orang (istri dan adik ipar). Su, Sahr, dan MR melakukan pembunuhan bersama dengan orang lain. Hal ini menandakan bahwa sebelum membunuh, mereka telah merencanakan dengan matang. Pada umumnya, tindakan pembunuhan didasari oleh kondisi kekecewaan atau sakit hati.

Pada kasus Sahr merasa sakit hati karena korban (Ton) menggoda istrinya. Padahal antara Sahr dengan Ton bersahabat baik. Mereka pernah bekerjasama mereparasi barang-barang elektronik yang rusak. IPR melampiaskan rasa dendam kepada anak kandungnya sendiri, karena IPR merasa sakit hati akibat bercerai dengan istrinya. MR juga merasa sakit hati karena William tak mau membayar utang sebesar 800 juta rupiah. MR telah membantu usaha William dengan modal sebesar itu, tetapi tak ada niat baik untuk mengembalikan. Akhirnya MR merasa hilang kesabarannya dan kemudian ia tega membunuh William.

Sementara itu, Warja membunuh istrinya, Sunarsih karena Warja merasa terhalangi untuk berpoligami. Warja juga membunuh Ningsih, karena Warja merasa kuatir kejahatannya diketahui dan dilaporkan ke polisi oleh Ningsih. Yang terakhir, Su mau menjadi pembunuh karena tergiur untuk mendapatkan bayaran sebesar 6 juta rupiah. Su melakukan pembunuhan karena memiliki motif uang.

Bagi Merton, munculnya tindakan menyimpang sebagaimana dalam tulisan ini tentang bagaimana seseorang melakukan tindakan membunuh yang dilakukan oleh individu adalah ketidakmampuan individu tersebut untuk bertindak sesuai dengan nilai normatif yang ada di masyarakat. Secara umum dapat dikatakan bahwa perilaku menyimpang adalah bentuk anomie dalam masyarakat. Anomie terjadi dalam masyarakat ketika ada keterputusan antara hubungan norma kultural dan tujuan dengan kapasitas terstruktur secara sosial dari anggota kelompok untuk bertindak sesuai dengan norma kultural (lihat Ritzer dan Goodman 2007). Secara umum Merton menghubungkan antara kultur, struktur, dan anomie. Kultur didefinisikan sebagai seperangkat nilai normatif yang terorganisasi yang menentukan perilaku bersama anggota masyarakat. Dalam hal ini, kultur menjadi buku panduan yang digunakan oleh semua anggota masyarakat untuk berperilaku.

Struktur didefinisikan sebagai seperangkat hubungan sosial yang terorganisasi yang melibatkan seluruh anggota masyarakat untuk terlibat di dalamnya. Sedangkan anomie didefinisikan sebagai sebuah keterputusan hubungan antara struktur dan kultur yang terjadi jika ada suatu keretakan atau terputusnya hubungan antara norma kultural dan tujuan-tujuan dengan kapasitas yang terstruktur secara sosial dari anggota dalam kelompok masyarakat untuk bertindak sesuai dengan nilai kultural tersebut (Merton, 1968: 216).

Perilaku menyimpang dalam hal ini dilihat sebagai ketidakmampuan seorang individu untuk bertindak sesuai dengan norma, tujuan, dan caracara yang diperbolehkan dalam masyarakat. Dalam hal ini, integrasi yang dilakukan oleh individu tersebut tidak lah bersifat menyeluruh. Tentu saja hal ini tidak berarti bahwa setiap orang dapat berintegrasi sepenuhnya. Dapat dikatakan bahwa tidak ada masyarakat yang terintegrasi secara penuh, di mana Merton melihat bahwa integrasi yang terjadi di masyarakat tidak lah sama baik secara kualitas maupun kuantitas (Maliki 2003). Dalam analisis fungsionalnya, Merton melihat bahwa motif-motif dalam integrasi tidak selalu 
membawa motif yang diinginkan (intended motif), namun juga motif-motif yang tidak diinginkan (unintended motif). Adanya fungsi manifes dan laten dalam integrasi berarti bahwa integrasi menyebabkan adanya pihak yang mengalami disintegrasi atau dalam bahasa yang lebih kasar, integrasi justru memiliki pengaruh besar atas terjadinya disintegrasi.

Pandangan ini tentu saja membawa konsekuensi yang lebih besar: anomie yang terjadi di masyarakat, yang berujung dengan terjadinya penyimpangan adalah 'efek samping' atau motif yang tidak diinginkan (unintended motif) dari integrasi dalam masyarakat. Merton membedakan antara fungsi dan disfungsi. Bagi Merton, fungsi adalah seluruh konsekuensi yang terlihat dan berguna bagi adaptasi atau pengaturan dari sistem yang telah ada, sedangkan disfungsi merupakan konsekuensi yang terlihat yang mengurangi adaptasi atau pengaturan dalam satu sistem (Merton, 1968:105). Selain membedakan antara fungsi dan disfungsi, Merton juga membedakan antara fungsi manifes dan fungsi laten. Fungsi manifest didefinisikan sebagai seluruh konsekuensi objektif yang berpengaruh pada pengaturan atau adaptasi dari suatu sistem yang diinginkan dan diakui oleh seluruh bagian sistem itu, sedangkan fungsi manifest adalah kebalikannya, yakni konsekuensi objektif yang berpengaruh pada pengaturan dan adaptasi dari satu sistem yang tidak diinginkan dan tidak akui (Merton, 1968:105).

Secara sederhana, dapat dikatakan bahwa perilaku menyimpang yang terjadi di kalangan subjek dalam penelitian ini merupakan adanya konflik antara norma-norma yang berlaku di masyarakat dengan cara-cara dan tujuan-tujuan yang dilakukan oleh individu. Oleh karena itu, Merton membagi keadaan ini dalam lima kategori sebagai berikut.
1. 'Conformity' atau individu yang terintegrasi penuh dalam masyarakat baik yang tujuan dan cara-caranya 'benar dalam masyarakat'.

2. 'Innovation' atau individu yang tujuannya benar, namun cara-cara yang dipergunakannya tidak sesuai dengan yang diinginkan dalam masyarakat.

3. 'Ritualism' atau individu yang salah secara tujuan namun cara-cara yang dipergunakannya dapat dibenarkan.

4. 'Retreatism' atau individu yang salah secara tujuan dan salah berdasarkan cara-cara yang dipergunakan.

5. 'Rebellion' atau individu yang meniadakan tujuan-tujuan dan cara-cara yang diterima dengan menciptakan sistem baru yang menerima tujuan-tujuan dan cara-cara baru.

\section{Keterbatasan Penelitian}

Penelitian ini bersifat kualitatif dengan menggunakan data primer, sehingga data penelitian ini sangat tergantung dari subjektivitas sumber data yang telah tersedia. Apabila data kurang lengkap, maka analisis penelitian pun menjadi kurang akurat, akibatnya juga akan memengaruhi hasil kesimpulannya.

Subjek penelitian ini berjumlah 5 orang dan terbatas sehingga hasil kesimpulan penelitian ini tak bisa digunakan untuk menggeneralisasi pada kasus-kasus yang lain. Dengan bahasa lain kiranya mungkin untuk memberikan nuansa lain dengan variasi temuan dalam kasus-kasus yang berbeda. Karena itu, siapa pun haruslah bersikap hati-hati dalam memanfaatkan hasil penelitian untuk melihat kasus-kasus pembunuhan lainnya. Demikian juga adanya dengan tulisan ini, perlu kiranya untuk memberikan varian baru lainnya dalam penelitian berikutnya. 


\section{KESIMPULAN}

Dalam penelitian ini, ditemukan bahwa pembunuhan bisa dilakukan oleh siapa pun, terutama kaum laki-laki. Pelaku pembunuhan berusia 14-35 tahun. Ada 4 motif yang mendasari pembunuhan yaitu motif uang, motif balas dendam, motif berpoligami, dan motif menagih utang-piutang. Pembunuhan bisa dilakukan dengan seorang diri, tetapi juga bisa dilakukan bersama orang lain. Cara membunuh dalam kasus ini dengan menggunakan alat, tetapi juga bisa dilakukan dengan tanpa alat.

Senada dengan temuan dari Studi Eko Hariyanto ditinjau dari elemen-elemen situasionalnya, ditemukan bahwa motivasi para pelaku umumnya merupakan motivasi ekspresif yang muncul saat terjadi pertengkaran antar pribadi yang kian memuncak; mayoritas pembunuhan melibatkan kenalan, selebihnya melibatkan anggota keluarga sendiri dan orang asing 1 tidak dikenal sebelumnya; korban umumnya berperan aktif dalam interaksi; lokasi fisik yang paling berbahaya bagi terjadinya pembunuhan adalah di dalam rumah korban sendiri dan di jalanan umum serta tempat umum lainnya. Peristiwa pembunuhan lebih sering terjadi pada malam hari. Senjata tajam seperti pisau, golok, badik, dan clurit merupakan senjata yang paling umum digunakan pelaku untuk menusuk atau membacok korbannya (eko hariyanto, 2015).

Senjata yang mematikan tersebut kebanyakan sengaja dibawa pelaku, namun ada pula yang ditemukan di tempat kejadian atau direbut dari tangan korban. Peristiwa pembunuhan paling sering dilakukan dengan cara keroyokan. Sesaat sebelum peristiwa pembunuhan terjadi, umumnya baik pelaku ataupun korban diketahui habis mengonsumsi alkohol dan/atau obat-obatan terlarang. Temuan ini menimbulkan dugaan bahwa alkohol atau obat-obatan terlarang inilah yang memengaruhi atau merangsang pelaku dan korban sehingga menjadi lebih aktif (baca: agresif) dalam proses interaksi di antara keduanya.

Dari hasil analisis data terungkap bahwa peristiwa pembunuhan itu merupakan akibat dari suatu perselisihan atau konflik antar pribadi yang kian memuncak di antara pelaku dengan korban. Interaksi sosial yang berakhir dengan pembunuhan ini umumnya berlangsung dalam enam tahapan menurut urutan waktunya. Temuan ini tampaknya relatif bersesuaian dengan kerangka pemikiran yang digunakan dalam penelitian ini.

Tahap pertama menggambarkan bahwa proses interaksi tersebut umumnya dibuka (diawali) oleh korban (victim precipitated) dengan cara melakukan: serangan terhadap pelaku atau memprovokasi secara verbal atau isyarat fisik yang bernada penghinaan terhadap pelaku. Menurut data yang terkumpul ditemukan bahwa tindakan korban tersebut di atas oleh pelaku umumnya ditafsirkan sebagai tindakan yang mengancam dan membahayakan jiwanya, dan seringkali juga dianggap sebagai penghinaan terhadap kehormatan dan harga diri pelaku. Kemudian dengan berlandaskan pada hasil interpretasi ini pelaku umumnya lalu menyusun rencana tindakan balasan (umumnya berupa tindak kekerasan) yang bersifat potensial, belum merupakan tingkah laku nyata. Rencana tindakan kekerasan oleh pelaku ini umumnya pada akhirnya direalisasi dalam bentuk tindak kekerasan nyata pada tahapan interaksi berikutnya bila sikap dan perilaku korban tetap tidak dapat ditoleransinya. Tahapan ini sering disebut sebagai tahapan kedua interaksi.

Pada tahap berikutnya, yakni tahap ketiga, pelaku benar-benar merespons provokasi korban demi menyelamatkan jiwa, ataupun harga diri dan kehormatannya. Respons pelaku umumnya 
berupa tantangan verbal yang menghina dan mengancam korban, dan terkadang juga dalam bentuk serangan fisik terhadap korban. Tahap keempat, yang mencerminkan respons korban terhadap reaksi balik pelaku pada tahap sebelumnya, memperlihatkan bahwa korban umumnya menerima tantangan verbal ataupun serangan fisik pelaku dengan memberikan ekspresi verbal yang menantang balik maupun dengan melakukan serangan fisik berikutnya. Pada tahap ini tampak jelas bahwa audiens yang ada di sekitar tempat kejadian umumnya aktif mendukung matangnya perselisihan antara pelaku-korban hingga berakhir dengan pembunuhan.

Dengan adanya kesepakatan kerja secara implisit ataupun eksplisit antara pelaku dengan korban bahwa kekerasan merupakan cara yang paling tepat untuk menyelesaikan konflik di antara mereka dan adanya senjata serta dukungan dan audiens, maka pada tahap kelima ini, keduanya terlibat perkelahian nyata yang kemudian berakhir dengan kematian korban. Tahap keenam yang merupakan tahap penutup interaksi menggambarkan bahwa setelah korban tewas umumnya pelaku melarikan diri, terlebih bila hubungan antara korban dengan pelaku hanya sebatas kenalan apalagi orang yang tidak dikenalnya. Namun bila korban adalah sanak keluarganya sendiri umumnya pelaku segera menyerahkan diri kepada polisi. Pada tahap ini audiens pun umumnya segera melaporkan peristiwa pembunuhan yang terjadi kepada polisi, Namun tetap harus disadari bahwa tahapan interaksi seperti ini tidak berlaku untuk kasus-kasus pembunuhan berikut ini: pembunuhan karena kekerasan kolektif primitif; pembunuhan yang bermotif politik; pembunuhan karena motif bayaran (yang dilakukan oleh pembunuh bayaran) dan pembunuhan di mana pelakunya mengidap kelainan jiwa, misalnya paranoids.

\section{SARAN}

Bagi peneliti lain yang hendak melakukan penelitian kriminalitas dengan topik pembunuhan, bisa disarankan untuk menggunakan pendekatan kuantitatif. Bila dengan menggunakan pendekatan kualitatif, seorang peneliti bisa mengambil data primer yang dilakukan secara langsung terhadap pelaku pembunuhan. Penelitian juga bisa dilakukan dengan melihat latar-belakang kepribadian, pengasuhan dan pengendalian emosi diri pelaku pembunuhan.

Penelitian kualitatif bisa juga dilakukan terhadap saudara atau keluarga dekat dari korban pembunuhan. Misalnya gambaran stress dan coping-stress orangtua yang anaknya menjadi korban pembunuhan, atau gambaran proses memaafkan orangtua terhadap pelaku pembunuhan yang telah membunuh anaknya.

\section{DAFTAR PUSTAKA}

Abubakar, Zubairu, Ghani; A comparative study of urban crime between Malaysia and Nigeria. Journal of Urban Management $\mathrm{xxx}(\mathrm{xxxx}) \mathrm{xxx}-\mathrm{xxx}$.

Allely, Clare S., Helen Minnis, Lucy Thompson, Philip Wilsonb, Christopher Gillberg. 2016. Neurodevelopmental and Psychosocial Risk Factors in Serial Killers and Mass Murderers. Sage, (p.21-35).

Belur, Jyoti, Nick Tilley, Nayreen Daruwalla, Meena Kumar, Vinay Tiwari, David Osrin. 2015. The social construction of 'dowry deaths'. Procedia - Social and Behavioral Sciences 165, 121-130.

Caman, Shilan, Marianne Kristiansson, Sven Granath, Joakim Sturup. 2015. Trends in rates and characteristics of intimate partner homicides between 1990 and 2013. Sage, (p.1-15). 
Denzin, Norman K., Yvonna S. Lincoln. 2011. The Sage Handbook of Qualitative Research. Jakarta: Pustaka Pelajar.

Hariyanto, Eko. 2015. Pembunuhan sebagai Hasil Interaksi Sosial Ditinjau dari Persepsi Pelaku: Studi Kasus Terhadap Empat Puluh Dua Kasus Pembunuhan. Laporan Penelitian UI. Jakarta: Universitas Indonesia.

Ilie Magdalena Ioana. 2013. No One is Born a Serial Killer! Procedia - Social and Behavioral Sciences 81, 324-328.

Janke, Katharina, Carol Propper, Michael A. Shields. 2012. Assaults, Murders and Walkers: The impact of violent crime on physical activity. Procedia - Social and Behavioral Sciences 42, 260-283

John L. Oliffe, R.N., Ph.D., Christina S.E., Han, M.A., Murray Drummond, Ph.D., Estephanie Sta. Maria, B.A., Joan L. Bottorff, Ph.D., and Genevieve Creighton, Ph.D. 2015. Men, Masculinities, and Murder-Suicide. Procedia - Social and Behavioral Sciences 125, 111-127

Joseph Murray, Daniel Ricardo de Castro Cerqueira, Tulio Kahn. 2013. Crime and Violence in Brazil: Systematic Review of Time Trends, Prevalence Rates and Risk Factors. J. Murray et al. Aggression and Violent Behavior 18, 471-483.

Josja J Rokven, Gijs de Boer, Jochem Tolsma, Radboud, Stijn Ruiter. How Friends' Involvement in Crime Affects the Risk of Offending and Victimization.

Mazlan Bin Che Soh. 2015. Crime and Urbanization: Revisited Malaysian Case. Procedia - Social and Behavioral Sciences 197, 2484-2489.

Mike Males. 2015. Age, Poverty, Homicide, and Gun Homicide: Is Young Age or Poverty Level the Key Issue? Sage, p.1-12.
Murray, Joseph, Daniel Ricardo de Castro Cerqueira, Tulio Kahn. 2015. Crime and Violence in Brazil: Systematic Review of Time Trends, Prevalence Rates and Risk Factors. Procedia - Social and Behavioral Sciences 65, 12-30.

Mohit, Mohammad Abdul, Mohamed Hassan Elsawahli Hannan. 2012. A Study of Crime Potentials in Taman Melati Terrace Housing in Kuala Lumpur: Issues and Challenges. Procedia - Social and Behavioral Sciences 42, 271-283.

Masykur, Achmad Mujab. 2012. Remaja dan Pembunuhan (Sebuah Studi FenomenologiForensik pada Remaja Pelaku Pembunuhan di Lapas Anak Kutoarjo).

Michael C. Dillbeck and Kenneth L. Cavanaugh. 2015. Societal Violence and Collective Consciousness: Reduction of U.S. Homicide and Urban Violent Crime Rates. Procedia - Social and Behavioral Sciences 82, 24-38.

Michael C. Dillbeck and Kenneth L. Cavanaugh. 2015. Societal Violence and Collective Consciousness: Reduction of U.S. Homicide and Urban Violent Crime Rates.

Moleong, L.J. 2008. Metodologi Penelitian Kualitatif. Bandung: PT Remaja Rosdakarya.

Octaviani, Sefti. 2015. Analisis Kriminologis Kejahatan Pembunuhan Berencana yang Dilakukan oleh Pelaku Terhadap Mantan Kekasih.

Rebecca M. Blank. 2015. Poverty, Policy, and Place: How Poverty and Policies to Alleviate Poverty Are Shaped by Local Characteristics. Procedia - Social and Behavioral Sciences 197, 2425-2429.

Robin A. Robinson, Simon Visiting Professor, David Gadd. 2015. Annihilation Anxiety and Crime. Sage, p.185-205. 
Soltankhah, Shapoura, Rahmani, M., Akbari, B. Darvishi. 2013. Comparison between Early Maladaptive Schema with Psychological Resiliency of the Criminals Murder, Drug Trafficking, Rape. Procedia - Social and Behavioral Sciences 81, 329-348.

Stretesky, Paul B., Michael A. Long, Northumbria, Michael J. Lync. A Cross-national Study of the Association between Natural Resource Rents and Homicide Rates, 2000$12 h$.
Tony McEnery, Mark McGlashan, Robbie Love. 2014. Press and Social Media Reaction to Ideologically Inspired Murder: The case of Lee Rigby. Procedia - Social and Behavioral Sciences 72, 28-50.

Widyatmoko Cikal, Ika Febrian Kristiana. 2014. Studi Kasus Pembunuhan yang Dilakukan oleh Remaja Narapidana di Lapas Kedung Pane Semarang. 